\title{
Evaluation of Salmonella typhi dipstick for detection of IgM antibodies from suspect Typhoid fever patient
}

\author{
M. Hatta ${ }^{1}$, L. Chairuddin ${ }^{1}$, H.L. Smith ${ }^{2}$
}

\begin{abstract}
Abstrak
Dipstik Salmonella typhi telah dikembangkan untuk deteksi antibodi IgM spesifik terhadap S. typhi pada manusia. Pada studi ini, telah diperiksa 195 sampel serum dari pasien tersangka demam tifoid dengan masa demam 10,1 $\pm 0,5$ hari menggunakan metode dipstik dan kultur darah. Hasil yang diperoleh adalah dipstik positif 72 sampel (36,9\%) dan kultur darah positif 29 sampel (14,9\%). Pada 113 sampel dengan masa demam kurang dari 10 hari, hasil positif pada pemeriksaan dipstik adalah 51 sampel $(45,1 \%)$ dan kultur sebesar 21 sampel (18,6\%). Dari hasil tersebut di atas, pada hari ke 10 demam, metode dipstik lebih sensitif dibandingkan dengan kultur darah S. typhi. Hasil positif dipstik secara bermakna lebih tinggi dari kultur darah (tes statistik Fischer, $p<0,01$ ). Disimpulkan, dipstik S. typhi mungkin bermanfaat untuk deteksi antibodi IgM untuk kasus tersangka demam tifoid, dan dapat digunakan untuk studi epidemiologi infeksi S. typhi. Studi lanjutan untuk membandingkan metode dipstik dengan PCR, serta untuk melihat spesifitas metode ini masih berlangsung.
\end{abstract}

\begin{abstract}
Salmonella typhi Dipstick have been developed for detection of IgM antibodies specific against $\mathrm{S}$. typhi on human. In this study, we examined 195 sera from suspect typhoid fever patients with the mean of fever $10.1 \pm 0.5$ days by the Dipstick method and compared with blood culture. From 195 suspected typhoid fever, we found positive to Dipstick and culture were 72 samples (36.9\%) and 29 samples $(14.9 \%)$, respectively. On cases with fever less than 10 days, from 113 samples, the positive rate for Dipstick and culture were 51 samples $(45.1 \%)$ and 21 (18.6\%), respectively. From data shown above, the Dipstick method is more sensitive in detecting IgM antibodies than blood culture detection of $\mathrm{S}$. typhi in day 10 after fever. Also, the positivity rate of Dipstick was significantly higher than the positivity rate of blood culture (fischer exact test, $p<0.01$ ). In conclusion, S. typhi Dipstick may be useful for detection IgM antibodies from suspected typhoid fever patients and may benefit as epidemiological tool for S. typhi infection. More study is still in progress to compare the Dipstick method nd PCR from blood and to explore the specificity of this method.
\end{abstract}

\footnotetext{
${ }^{1}$ Microbiology Department, Hasanuddin University, Ujung Pandang, Indonesia

${ }^{2}$ Royal Tropical Institute, The Netherland.
} 